\title{
Epidemic of Mungbean Yellow Mosaic Virus (MYMV) Disease of Soybean: A Potential Threat in Changing Weather under Agro-climatic Conditions of Jabalpur, Madhya Pradesh
}

\author{
Kunika Silodia*, Usha Bhale and M. S. Bhale
}

Dept. of Plant Pathology, JNKVV, Jabalpur, M.P. (482 004), India

\section{Corresponding Author}

Kunika Silodia

e-mail: silodiyak@gmail.com

\author{
Article History \\ Article ID: 3 C0316 \\ Received in $05^{\text {th }}$ October, 2017 \\ Received in revised form $25^{\text {th }}$ November, 2017 \\ Accepted in final form $3^{\text {rd }}$ December, 2017
}

\begin{abstract}
In all 11 major diseases were observed at VC-V3, R1-R3 and R5-R6 stage at pre-selected farmer's field of 8 villages covering 24 locations employing fixed plot monitoring method. An epidemic of MYMV was experienced which had never been major disease problem- threat under Jabalpur $\left(22^{\circ} 49^{\prime}\right.$ and $20^{\circ} 80^{\prime} \mathrm{N}$ latitude and $70^{\circ} 21^{\prime}$ and $80^{\circ} 58^{\prime}$ East longitude at an altitude of $411.78 \mathrm{MSL}$ ) conditions. In the changing weather conditions, the congenial temperature and humidity during first and second fortnight of August, 2015 boosted up the population of virus vector whitefly and epidemic of MYMV. In the first week of August, MYMV appeared as scattered specks on few top leaves in JS 335. Within a short period of 10-12 days the disease spread rapidly and covered more than $90 \%$ plant population. In the first week of August, at initial stage, presence of whiteflies ( 2 flies/leaf) was noticed. During $31^{\text {st }}$ standard week (July, 2015), the rainfall was $149.40 \mathrm{~mm}$ and maximum temperature 29.8 and minimum $23.6^{\circ} \mathrm{C}$ (av. $26.7^{\circ} \mathrm{C}$ ) with average relative humidity $80 \%$ was noticed.
\end{abstract}

Keywords: MYMV, soybean diseases distribution, plant growth stages whiteflies

\section{Introduction}

Soybean [Glycine max (L.) Merrill], is valued due to high quality protein (40-42\%) and oil content (18-20\%) and on account of its ability to fix biological nitrogen $270 \mathrm{~kg} \mathrm{~N} / \mathrm{ha}$ as compared to $150 \mathrm{~kg} \mathrm{~N} \mathrm{ha}^{-1}$ by other pulses. The crop is grown on 55.5 lakh ha with a production of 51.6 lakh MT and productivity of 930 $\mathrm{kg} \mathrm{ha}^{-1}$. The golden nugget, soybean] is one of the five sacred grains, was originated from China as early as 2853 BC. The then, Emperor Sheng-Nung valued the crop for protein and oil contents (Hymowitz, 1970). Seeds of grain legume, soybean contains $40 \%$ oil and $20 \%$ quality protein apart from having a unique quality of utilizing atmospheric nitrogen through biological nitrogen fixation. About $270 \mathrm{~kg} \mathrm{~N} \mathrm{ha}^{-1}$ is fixed by soybean as compared to $58-157 \mathrm{~kg} \mathrm{~N}^{-1}$ by other pulses (Hoque, 1978; Tiwari, 2001). In the present world, soybean has become the largest source of vegetable oil and protein and its large scale cultivation is concentrated in Argentina, Brazil, China, India and USA (Anonymous, 2017). Among 130 diseases observed globally,35 diseases are economically important under agro-conditions of India, as observed at various stages of crop growth (Hartman and Hill, 2010; Gupta and Chouhan, 2005).The present paper deals with the incidence of various diseases at different vegetative and reproductive stages of the crop under agro-climatic conditions of Jabalpur, Madhya Pradesh (Silodia, 2016).

\section{Materials and Methods}

\subsection{Status of diseases}

\subsubsection{Stage of the crop}

The incidence of diseases was recorded at three stages viz., VC-V3 (cotyledon spread to $3^{\text {rd }}$ node stage; 3 nodes on the main stem with fully developed leaves beginning with unifoliate node); R1-R3 (one flower at any node, pod 0.5 $\mathrm{cm}$ long at one of the four uppermost node); R5-R6 (Beans beginning to develop, pod contains full size green beans).

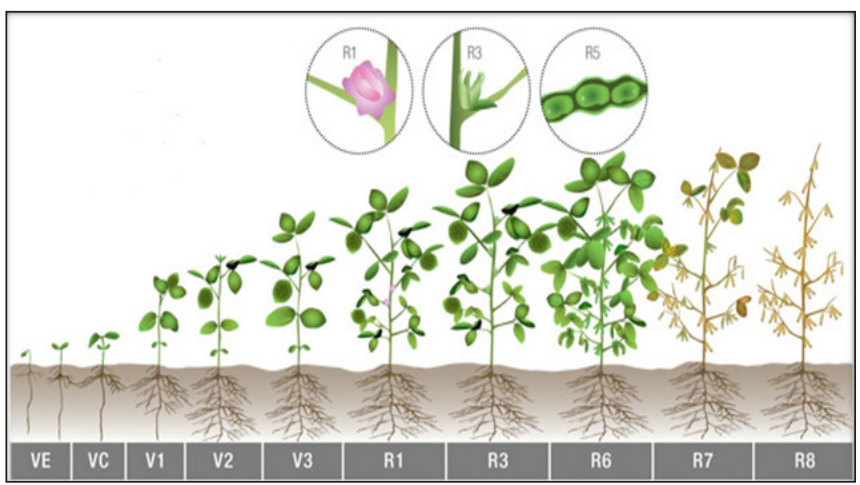




\subsubsection{Location}

Disease incidence was recorded at pre-selected farmers field of eight villages covering 24 locations around Jabalpur $\left(22^{\circ} 49^{\prime}\right.$ and $20^{\circ} 80^{\prime} \mathrm{N}$ latitude and $70^{\circ} 21^{\prime}$ and $80^{\circ} 58^{\prime}$ East longitude at an altitude of $411.78 \mathrm{MSL}$ ) at fortnight intervals and meteorological data were also recorded.

\subsection{Incidence of diseases}

The diseases were identified on the basis of typical field symptoms. The incidence of major diseases was recorded on randomly selected total 100 plants in a particular plot of field. The diseases were identified initially on the basis of visual and typical field symptoms and later confirmed by microscopic observations.

During the study, total and infected plants were counted to calculate the disease incidence as per formula advocated by Singh and Singh (2000).

$\mathrm{PDI}=\frac{\text { TIP }}{\text { TPO }} \times 100$

Where,

$\mathrm{PDI}=$ Percent disease incidence i.e. percent plant infected

TIP $=$ Total number of infected plants

TPO=Total number of plant observed

\section{Results and Discussion}

\subsection{Incidence of disease at VC-V3}

At VC-V3 stage, incidence of seedling rot (Sclerotium rolfsii) was observed in the range of $2-14 \%$ during fixed plot monitoring at eight villages (Table 1 ). The seedling decay was in the range of $2-12 \%$. The microscopic examination of blighted, dried and dead seedlings revealed the presence and association of species of Fusarium, Colletotrichum and Rhizoctonia. Observations were taken during $2^{\text {nd }}$ fortnight of June to $1^{\text {st }}$ fortnight of July and the average temperature was $28.42{ }^{\circ} \mathrm{C}$ and relative humidity was $41.75 \%$.

Incidence of common mosaic and yellow mosaic expressed upto 5\%. Hartman and Hill (2010) reported the early season diseases as seed-decay and damping-off, mid-season crop diseases including leaf spots, pustules and anthracnose and various viral diseases, whereas late season crop diseases included charcoal root rot, pod blight and stem canker.

\subsection{Incidence of disease at R1-R3}

At R1-R3 stage, five diseases were observed under variable proportions. Leaf spots due to Alternaria alternata and Cercospora sojina ranged upto 30 and $15 \%$, respectively. During the period of observation ( $2^{\text {nd }}$ fortnight of August to $1^{\text {st }}$ fortnight of September) average temperature was $27.7^{\circ} \mathrm{C}$ and relative humidity $76.5 \%$. Incidence of aerial blight (Rhizoctonia solani) and bacterial pustule (Xanthomonas axonopodis pv. glycines) ranged up to 15 and $17 \%$, respectively.

\subsection{Incidence of MYMV}

A sudden outbreak of MYMV was recorded during the $2^{\text {nd }}$
Table 1: Incidence of major diseases of soybean at VC-V3 stage at farmers' field during Kharif 2015 as recorded under fixed plot survey method

\begin{tabular}{|c|c|c|c|c|c|}
\hline \multirow[t]{2}{*}{ Location } & \multicolumn{5}{|c|}{ Per cent disease incidence* } \\
\hline & $S R$ & SD & $\mathrm{CM}$ & YM & MYMV \\
\hline \multicolumn{6}{|l|}{ Patan } \\
\hline Location 01 & 05.0 & 06.0 & 02.0 & 00.0 & 00.0 \\
\hline Location 02 & 14.0 & 00.0 & 00.0 & 00.0 & 00.0 \\
\hline Location 03 & 03.0 & 05.0 & 00.0 & 01.0 & 00.0 \\
\hline \multicolumn{6}{|l|}{ Katanga } \\
\hline Location 01 & 03.0 & 04.0 & 00.0 & 00.0 & 00.0 \\
\hline Location 02 & 07.0 & 11.0 & 03.0 & 02.0 & 00.0 \\
\hline Location 03 & 04.0 & 03.0 & 01.0 & 04.0 & 00.0 \\
\hline \multicolumn{6}{|l|}{ Panagar } \\
\hline Location 01 & 02.0 & 00.0 & 00.0 & 00.0 & 00.0 \\
\hline Location 02 & 12.0 & 03.0 & 00.0 & 05.0 & 00.0 \\
\hline Location 03 & 10.0 & 04.0 & 03.0 & 00.0 & 00.0 \\
\hline \multicolumn{6}{|l|}{ Maharajpur } \\
\hline Location 01 & 10.0 & 02.0 & 03.0 & 00.0 & 00.0 \\
\hline Location 02 & 05.0 & 05.0 & 02.0 & 00.0 & 00.0 \\
\hline Location 03 & 04.0 & 00.0 & 00.0 & 04.0 & 00.0 \\
\hline \multicolumn{6}{|l|}{ Jabalpur - } \\
\hline Location 01 & 03.0 & 04.0 & 00.0 & 00.0 & 00.0 \\
\hline Location 02 & 07.0 & 07.0 & 04.0 & 00.0 & 00.0 \\
\hline Location 03 & 06.0 & 04.0 & 03.0 & 00.0 & 00.0 \\
\hline \multicolumn{6}{|l|}{ Bhedaghat } \\
\hline Location 01 & 09.0 & 05.0 & 02.0 & 00.0 & 00.0 \\
\hline Location 02 & 00.0 & 09.0 & 05.0 & 00.0 & 00.0 \\
\hline Location 03 & 00.0 & 03.0 & 04.0 & 03.0 & 00.0 \\
\hline \multicolumn{6}{|l|}{ Tilwara } \\
\hline Location 01 & 00.0 & 02.0 & 05.0 & 05.0 & 00.0 \\
\hline Location 02 & 00.0 & 11.0 & 02.0 & 03.0 & 00.0 \\
\hline Location 03 & 00.0 & 10.0 & 00.0 & 03.0 & 00.0 \\
\hline \multicolumn{6}{|l|}{ Barela road } \\
\hline Location 01 & 11.0 & 12.0 & 02.0 & 00.0 & 00.0 \\
\hline Location 02 & 03.0 & 00.0 & 00.0 & 00.0 & 00.0 \\
\hline Location 03 & 00.0 & 05.0 & 01.0 & 01.0 & 00.0 \\
\hline Range & 02-14 & $02-12$ & $01-05$ & 01-05 & 00.0 \\
\hline
\end{tabular}

SR: Sclerotial Rot; SD: Seedling decay; CM: Common mosaic; YM: Yellow Mosaic; * Observations made on total 100 plants in each field during II fortnight of June to I fortnight of July 2015; Average temperature $28.42{ }^{\circ} \mathrm{C} \&$ relative humidity $41.75 \%$. 
week of August and within a period of 10-15 days, the incidence spread in the range of $43-70 \%$ as observed at eight villages covering 24 locations. In some fields, the viral disease incidence was more than $90 \%$ and practically each plant was infected. MYMV disease had never been a major threat under Jabalpur conditions. In the $1^{\text {st }}$ week of August, presence of vector, whiteflies ( 2 flies leaf $^{-1}$ ) was noticed. During $31^{\text {st }}$ week (July, 2015) the rainfall was $149.40 \mathrm{~mm}$ and the average temperature was $26.7^{\circ} \mathrm{C}$ with average relative humidity $80 \%$. Within two weeks, the population of whiteflies was almost tripled in number and increased from 7-25 flies/leaf. High humidity (more than 93\%) with $104.6 \mathrm{~mm}$ rainfall and only three hours sunshine period triggered the development of the disease spread of vector population that resulted in the epidemic of Mungbean Yellow Mosaic Virus disease (MYMV).

Mungbean Yellow Mosaic Virus disease has never been a problem in central India; however different aspects of this disease have been well documented (Haq et al., 2010; Sunitha et al., 2013) (Table 2).

\subsection{Incidence of disease at R5-R6}

Pod blight complex involving a dominant fungus, Colletotrichum dematium was recorded in the range of $4-21 \%$. The infected pods turned brown and shriveled. The average incidence of dry root rot (Rhizoctonia bataticola) was in the range of 2-27\% (Table 3). Pod blight complex has been mentioned (Bhatia et al., 2002; Sharma and Shukla, 1993).Several diseases at VCV3, R1-R3 and R5-R6 stages have been described by workers (Gupta and Chouhan, 2005; Sarbhoy and Mahendra Pal, 1997; Dwivedi et al., 1991; Hussain and Khan, 1989).

\subsection{Progressive development of mungbean yellow mosaic} virus disease (MYMV)

\subsubsection{Development of MYMV}

Development of MYMV was recorded on pre- tagged soybean plants under field conditions in the research field. Incidence of scattered yellow specks was noticed on upper leaves (JS 335) on August 7, 2015 ( $32^{\text {nd }}$ standard week). The presence of whiteflies on middle leaves was 2 flies leaf $^{-1}$. In the previous week ( $31^{\text {st }}$ standard week, July, 2015) the rainfall was 149.40 $\mathrm{mm}$ and the average temperature was $26.7^{\circ} \mathrm{C}$ (maximum temperature 29.8 and minimum temperature $23.6^{\circ} \mathrm{C}$ ) with average relative humidity $80 \%$. In the second week of August ( $33^{\text {rd }}$ standard week) the incidence of MYMV increased up to $13 \%$ and during that period the rainfall was $116.80 \mathrm{~mm}$, with a relative humidity of $82 \%$ and $27.85^{\circ} \mathrm{C}$ average temperature. Within a period of seven days, the average population of whiteflies increased upto 7 flies/leaf. In the third week of August ( $34^{\text {th }}$ standard week) the incidence of disease boosted up to $60 \%$. In the fourth week of August, beyond $70 \%$ crop canopy was infected. At the same time, within a period of two weeks the population of whiteflies was almost tripled and increased from 7-25 flies leaf ${ }^{-1}$ (Table 4 and Figure 1).

Table 2: Incidence of major diseases of soybean at R1-R3 stage at farmers' field during Kharif 2015 as recorded under fixed plot survey method

\begin{tabular}{|c|c|c|c|c|c|c|}
\hline \multirow[t]{2}{*}{ Location } & \multicolumn{5}{|c|}{ Per cent disease incidence ${ }^{*}$} & \multirow[b]{2}{*}{ MYMV } \\
\hline & CLS & ALS & $A B$ & Rust & $\mathrm{BP}$ & \\
\hline Location 01 & 30.0 & 11.0 & 03.0 & 00.0 & 12.0 & 65.0 \\
\hline Location 02 & 11.0 & 00.0 & 10.0 & 00.0 & 15.0 & 70.0 \\
\hline Location 03 & 15.0 & 00.0 & 05.0 & 00.0 & 17.0 & 60.0 \\
\hline \multicolumn{7}{|l|}{ Katangi } \\
\hline Location 01 & 14.0 & 05.0 & 00.0 & 00.0 & 05.0 & 70.0 \\
\hline Location 02 & 25.0 & 05.0 & 07.0 & 00.0 & 03.0 & 45.0 \\
\hline Location 03 & 04.0 & 06.0 & 07.0 & 00.0 & 00.0 & 63.0 \\
\hline \multicolumn{7}{|l|}{ Panagar } \\
\hline$\overline{\text { Location } 01}$ & 05.0 & 07.0 & 15.0 & 00.0 & 00.0 & 65.0 \\
\hline Location 02 & 06.0 & 00.0 & 02.0 & 00.0 & 05.0 & 60.0 \\
\hline Location 03 & 11.0 & 03.0 & 05.0 & 00.0 & 00.0 & 55.0 \\
\hline \multicolumn{7}{|l|}{ Maharajpur } \\
\hline Location 01 & 03.0 & 00.0 & 00.0 & 00.0 & 00.0 & 59.0 \\
\hline Location 02 & 00.0 & 04.0 & 00.0 & 00.0 & 00.0 & 52.0 \\
\hline Location 03 & 10.0 & 05.0 & 02.0 & 00.0 & 04.0 & 55.0 \\
\hline \multicolumn{7}{|l|}{ Jabalpur } \\
\hline Location 01 & 14.0 & 07.0 & 05.0 & 00.0 & 00.0 & 58.0 \\
\hline Location 02 & 17.0 & 00.0 & 11.0 & 00.0 & 00.0 & 69.0 \\
\hline Location 03 & 12.0 & 02.0 & 10.0 & 00.0 & 03.0 & 65.0 \\
\hline \multicolumn{7}{|l|}{ Bhedaghat } \\
\hline Location 01 & 11.0 & 11.0 & 08.0 & 00.0 & 00.0 & 63.0 \\
\hline Location 02 & 00.0 & 14.0 & 12.0 & 00.0 & 05.0 & 66.0 \\
\hline Location 03 & 02.0 & 15.0 & 07.0 & 00.0 & 00.0 & 59.0 \\
\hline \multicolumn{7}{|l|}{ Tilwara } \\
\hline Location 01 & 05.0 & 12.0 & 06.0 & 00.0 & 00.0 & 49.0 \\
\hline Location 02 & 05.0 & 10.0 & 12.0 & 00.0 & 00.0 & 47.0 \\
\hline Location 03 & 00.0 & 10.0 & 02.0 & 00.0 & 00.0 & 60.0 \\
\hline \multicolumn{7}{|l|}{ Barela road } \\
\hline Location 01 & 03.0 & 05.0 & 10.0 & 00.0 & 00.0 & 45.0 \\
\hline Location 02 & 00.0 & 00.0 & 00.0 & 00.0 & 05.0 & 43.0 \\
\hline Location 03 & 00.0 & 02.0 & 08.0 & 00.0 & 11.0 & 69.0 \\
\hline Range & $02-30$ & $02-15$ & 02-15 & 0 & $03-17$ & $43-70$ \\
\hline
\end{tabular}

CLS: Cercospora leaf spot; ALS: Alternaria leaf spot; $A B$ : Aerial blight; BP: Bacterial pustule; *Observations made on total 100 plants in each field during II fortnight of August to I fortnight of September 2015; Average temperature 27.77 ${ }^{\circ} \mathrm{C} \&$ relative humidity $76.5 \%$ 
Table 3: Incidence of major diseases of soybean at R5-R6 stage at farmers' field during Kharif 2015 as recorded under fixed plot survey method

\begin{tabular}{|c|c|c|}
\hline \multirow[t]{2}{*}{ Location } & \multicolumn{2}{|c|}{ Per cent disease incidence ${ }^{*}$} \\
\hline & Pod blight complex & Dry root rot \\
\hline \multicolumn{3}{|l|}{ Patan } \\
\hline Location 01 & 05.0 & 11.0 \\
\hline Location 02 & 17.0 & 14.0 \\
\hline Location 03 & 21.0 & 07.0 \\
\hline \multicolumn{3}{|l|}{ Katangi } \\
\hline Location 01 & 14.0 & 05.0 \\
\hline Location 02 & 03.0 & 09.0 \\
\hline Location 03 & 10.0 & 11.0 \\
\hline \multicolumn{3}{|l|}{ Panagar } \\
\hline Location 01 & 10.0 & 13.0 \\
\hline Location 02 & 11.0 & 27.0 \\
\hline Location 03 & 17.0 & 20.0 \\
\hline \multicolumn{3}{|l|}{ Maharajpur } \\
\hline Location 01 & 12.0 & 10.0 \\
\hline Location 02 & 14.0 & 05.0 \\
\hline Location 03 & 17.0 & 00.0 \\
\hline \multicolumn{3}{|l|}{ Jabalpur } \\
\hline Location 01 & 19.0 & 19.0 \\
\hline Location 02 & 12.0 & 12.0 \\
\hline Location 03 & 07.0 & 05.0 \\
\hline \multicolumn{3}{|l|}{ Bhedaghat } \\
\hline Location 01 & 05.0 & 03.0 \\
\hline Location 02 & 04.0 & 00.0 \\
\hline Location 03 & 17.0 & 00.0 \\
\hline \multicolumn{3}{|l|}{ Tilwara } \\
\hline Location 01 & 13.0 & 00.0 \\
\hline Location 02 & 00.0 & 00.0 \\
\hline Location 03 & 05.0 & 02.0 \\
\hline \multicolumn{3}{|l|}{ Barela road } \\
\hline Location 01 & 00.0 & 05.0 \\
\hline Location 02 & 00.0 & 02.0 \\
\hline Location 03 & 05.0 & 00.0 \\
\hline Range & $04-21$ & $02-27$ \\
\hline
\end{tabular}

*Observations made on total 100 plants in each field during II fortnight of October to I fortnight of November 2015; Average temperature $24.4{ }^{\circ} \mathrm{C} \&$ relative humidity $65.8 \%$.
Table 4: Progressive development of MYMV disease

\begin{tabular}{lccccccc}
\hline August & SW; & PI & WP & TA & RH & RD & SS \\
\hline $1^{\text {st }}$ week & 32 & 03.00 & 02.00 & 27.70 & 80.0 & 2 & 4.6 \\
$2^{\text {nd }}$ week & 33 & 13.00 & 07.00 & 27.85 & 82.0 & 4 & 3.0 \\
$3^{\text {rd }}$ week & 34 & 60.00 & 25.00 & 27.45 & 76.0 & 1 & 7.4 \\
$4^{\text {th }}$ week & 35 & 70.00 & 30.00 & 27.15 & 84.5 & 5 & 3.0 \\
\hline
\end{tabular}

SW: Standard week; PI: \% incidence of MYMV; WP: Whitefly population; TA: Temperature average $\left({ }^{\circ} \mathrm{C}\right)$; $\mathrm{RH}$ : Relative humidity (\%); RD: Rainy days; SS: Sunshine (hrs day ${ }^{-1}$ )

— $\%$ incidence of Disease — Whitefly population

- Av Temperature — Relative humidity - Rainy days - Sunshine (hrs day ${ }^{-1}$ )

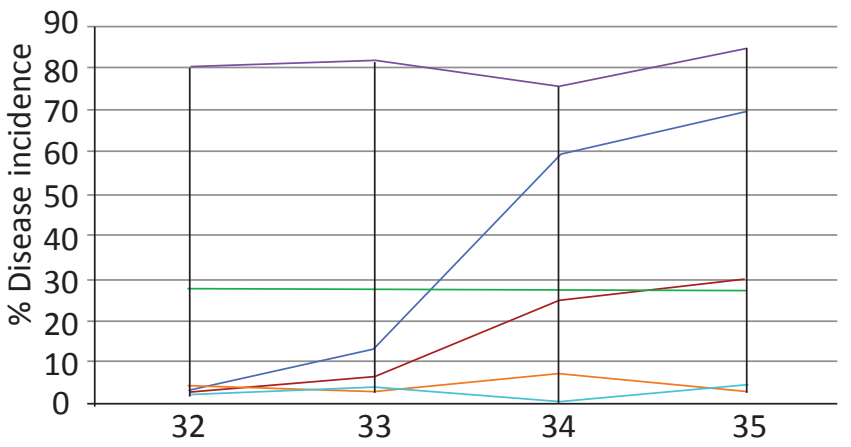

Standard week (August, 2015)

Figure 1: Progressive development of MYMV under field conditions (JS 335)

\section{Conclusion}

In all 11, soybean plant diseases were observed including leaf spots \& infection (Cercospora sojina, Alternaria alternata, Xanthomonas axonopodis and Rhizoctonia solani), root \& stem infection (Sclerotium rolfsii, Macrophomina phaseolina), pod infection (Colletotrichum dematium). In the changing weather conditions, corresponding with the congenial temperature $\left(27.77^{\circ} \mathrm{C}\right)$ and humidity $(76.5 \%)$ during $1^{\text {st }}$ fortnight of August, sudden outbreak of MYMV was experienced which had never been a major disease threat under Jabalpur conditions. Progressive disease development studies indicate that higher rainfall $(116.80 \mathrm{~mm})$ with greater number of rainy days (04) resulted in intense relative humidity (more than $75 \%$ ), that triggered the higher population of whiteflies(20-30/leaf) during second fortnight of August that resulted in epidemic of MYMV disease in soybean with more than $75 \%$ plant infection.

\section{Acknowledgment}

Senior author gratefully acknowledges the technical guidance by Dr. A.N. Srivastava (Soybean Plant Breeder), Dr. R.N. Pandey (AAU, Anand), Dr. G.K. Gupta (DSR Indore), Dr. S.N. Singh and Dr. G.K. Koutu (JNKVV, Jabalpur).

\section{References}

Anonymous, 2017. Sustaining soybean productivity and 
production in India. Strategy paper. National Academy of Agricultural Sciences, New Delhi, India.

Bhatia, V.S., Ansari, M.M., Gupta, G.K., 2002. Effect of foliar spray sprays of fungicides on germination and vigour of unweathered and field weathered seed of soybean varieties. Seed Research 30(2) 298-306.

Dwivedi, S.K., Pandey, S.N., Dwivedi, R.S., 1991. Post harvest fungi of seeds of some soybean cultivars. International Journal of Plant Diseases (2) 221-230.

Gupta, G.K., Chouhan, G.S., 2005. Symptoms Identification and Management of Soybean Diseases. Technical Bulletin no.10, National Research Centre for Soybean. Indore, 92.

Haq, Q.M.L., Ali, A., Malathi, V.G., 2010. Engineering resistance against Mungbean yellow mosaic India virus using Antisense RNA. Indian Journal of Virology 21(1) 82-85.

Hartman, G.L., Hill, C.B., 2010. Diseases of soybean and their management. The soybean: Botany, Production and uses, 276-299.

Hoque, N.S., 1978. Present availability of nitrogen from organic wastes and biological sources. Seminar on Nitrogen in Crop Production, December-January, 1977-1978, Dhaka

Hussain, S., Khan, B.A., 1989. Seed borne mycoflora of soybean in the Northwest Frontier province of Pakistan. Sarhad Journal of Agriculture 3(4), 421-424.
Hymowitz, T., 1970. On domestication on soybean. Economic Botany 24, 408-421.

Sarbhoy, A.K., Mahendra, P., 1997. Soybean rust: A threatening disease in India. In: Agnihotri, V.P., Sarbhoy, A.K., Singh, D.V. (Eds.), Management of threatening Plant Diseases of National Importance Malhotra Publishing House, New Delhi, 69-76.

Sharma, A.N., Shukla, A.K., 1993. Field screening of soybean germplasm for resistance to insect pests and diseases. Soybean Genetics Newsletter 20, 73-78.

Silodia, K., 2016. Investigations on epidemiology of soybean diseases with special reference to Mungbean Yellow Mosaic and its impact on sowing seed quality. M.Sc. (Ag.) thesis. Department of Plant Pathology, JNKVV, Jabalpur, MP, 84.

Sunitha, S., Shanmugapriya, G., Veluthambhi, B., Veluthambi, K., 2013. Mungbean yellow mosaic virus AC4 suppresses post-transcriptional gene silencing and an AC4 hairpin RNA gene reduces MYMV DNA accumulation in transgenic tobacco. Virus Gene 46, 496-504.

Tiwari, S.P., 2001. Shattering the production constraints in soybean based cropping system. JNKVV Research Journal 35(1\&2), 1-7. 